\title{
Canopy interception loss in a Pinus sylvestris var. mongolica forest of Northeast China
}

\author{
LI Yi ${ }^{1}$, CAI Tijiu ${ }^{1,2^{*}}$, MAN Xiuling ${ }^{2}$, SHENG Houcai ${ }^{2}$, JU Cunyong ${ }^{2}$ \\ ${ }^{1}$ Center for Ecological Research, Northeast Forestry University, Harbin 150040, China; \\ ${ }^{2}$ College of Forestry, Northeast Forestry University, Harbin 150040, China
}

\begin{abstract}
Pinus sylvestris var. mongolica is one of the main species to be afforested in deserts of China. But little work has been carried out on the canopy interception loss of this plant species. For researching the canopy interception loss of a natural $P$. sylvestris forest, we observed the gross precipitation, gross snowfall, throughfall and stemflow in a sample plot at the Forest Ecosystem Research Station of Mohe in the Great Khingan Mountains of Northeast China from July 2012 to September 2013. Considering the spatial variability of the throughfall, we increased the area rather than the number of collector and randomly relocated them once a week. The results demonstrated that the throughfall, stemflow, and derived estimates of rainfall and snowfall interception loss during the main rainy and snowy seasons were $77.12 \% \pm 5.70 \%, 0.80 \%, 22.08 \% \pm 5.51 \%$ and $21.39 \% \pm 1.21 \%$ of the incident rainfall or snowfall, respectively. The stemflow didn't occur unless the accumulated rainfall reached up to $4.8 \mathrm{~mm}$. And when the gross precipitation became rich enough, the stemflow increased with increasing tree diameters. Our analysis revealed that throughfall was not observed when rainfall was no more than $0.99 \mathrm{~mm}$, indicating that the canopy storage capacity at saturation was $0.99 \mathrm{~mm}$ for $P$. sylvestris forest.
\end{abstract}

Keywords: rainfall; snowfall; throughfall; stemflow; Great Khingan Mountains

Citation: LI Yi, CAI Tijiu, MAN Xiuling, SHENG Houcai, JU Cunyong. 2015. Canopy interception loss in a Pinus sylvestris var. mongolica forest of Northeast China. Journal of Arid Land, 7(6): 831-840. doi: 10.1007/s40333-015-0013-4

Deserts cover an area of approximately $45 \times 10^{6} \mathrm{~km}^{2}$, which occupy almost $30 \%$ of our planet's land surface, and a population close to $850 \times 10^{6}$ lives in desert regions (Shachnovich et al., 2008). A land area of $6 \times 10^{4}$ $\mathrm{km}^{2}$ becomes deserts every year due to the spread of desertification (Lanly, 1982) in arid and semi-arid lands (ASAL), which is predominantly the result of overgrazing and indiscriminate tree felling (Mitchell et al., 1998). The systematic afforestation on denuded lands with appropriate tree species could help alleviate the desertification by increasing firewood availability and thereby decreasing the pressure on natural vegetation. In ASAL, as water is a limiting factor for vegetation development, it is therefore of importance to ascertain the impact of large-scale afforestation on the local water balance (Shachnovich et al., 2008).

The rainfall interception of forested areas is an im- portant process in the catchment water balance (Herbst et al., 2008). It influences many hydrological processes, including infiltration, erosion, soil moisture distribution, sub-surface runoff and flood generation (Keim and Skaugset, 2003; Tsiko et al., 2012). But it is often disregarded or underestimated. Quantifying the amount of rainfall interception loss by tree canopy can be of considerable importance for the hydrological budgets in forested catchments (Whelan and Anderson, 1996). However, the accurate measurement of rainfall interception is difficultly carried out since it is influenced by many factors, including canopy structure, tree spacing, wind, rainfall intensity and evaporation (Hörmann et al., 1996; Gerrits and Savenije, 2011). Although the interception of rainfall has been modeled (e.g. Gash, 1979; Calder, 1996) to some extent, for implementing these models, a number of canopy

"Corresponding author: CAI Tijiu (E-mail: caitijiu1963@163.com)

Received 2014-12-02; revised 2015-06-09; accepted 2015-06-16

C Xinjiang Institute of Ecology and Geography, Chinese Academy of Sciences, Science Press and Springer-Verlag Berlin Heidelberg 2015 
characteristics and meteorological factors are necessary and these data are usually not available (Shachnovich et al., 2008). In order to determine the canopy interception loss, it is necessary to measure gross precipitation, throughfall and stemflow. Previous investigations demonstrated that canopy interception loss generally represents $9 \%-36 \%$ of gross precipitation (Hörmann et al., 1996; Roth et al., 2007; Levia et al., 2011), while it was estimated to be as much as $48 \%$ of gross precipitation in some coniferous forests (Rutter et al., 1975).

Pinus sylvestris var. mongolica as a pinus species has the characteristics of evergreen, drought and barren resistance and strong adaptability. These characteristics make it be the main afforestation tree in the deserts, farmland protection forests of Northeast China and urban greening in China. But most of the previous studies about it were focused on well-bred seedlings and cultivation techniques. There are at least two remaining questions regarding this species, i.e. what is its ability related to canopy interception loss and whether it is appropriate or not for a choice as the afforestation tree in the Great Khingan Mountains. The Great Khingan Mountains is the cradle of the Heilongjiang River and is the only forest zone of China located in a cold temperate zone. There is nearly half a year covered with snow, and the snowmelt is the main water supply during the drought period in early spring. Therefore, the snowfall interception loss should be meaningfully studied in this region. This paper provides a description of the precipitation interception loss of the natural $P$. sylvestris forest in the Great Khingan Mountains. In this study, we observed gross precipitation and throughfall from July 2012 to September 2013 within a $P$. sylvestris forest in the Great Khingan Mountains of Northeast China.

The aims of this study were to: (1) examine the gross precipitation (including rainfall and snowfall), throughfall and stemflow of the natural $P$. sylvestris forest; (2) analyze the characteristics of the stemflow impacted by tree diameter; and (3) determine the canopy interception (rainfall and snowfall) loss of this forest.

\section{Materials and methods}

\subsection{Study area}

The study site is located at the north slope of the Great Khingan Mountains and is administratively affiliated to the Mohe county, Heilongjiang province, China $\left(121^{\circ} 07^{\prime}-124^{\circ} 20^{\prime} \mathrm{E}, 52^{\circ} 10^{\prime}-53^{\circ} 33^{\prime} \mathrm{N}\right)$. Especially, it is also a part of the experimental area of an national forestry ecology system research station. As a memeber of Chinese Forest Ecosystem Research Network, the station was designed as an open study institution for all the researchers and was established and managed by Northeast Forestry University.

This site is dominated by the natural P. sylvestris forest and is approximately $8 \mathrm{~km}$ in length from east to west, $300 \mathrm{~m}$ in width from north to south (Fig. 1). Its southern side faces a road, and the other sides are adjacent to a natural broadleaved forest. This area has a long cold winter and short hot summer. Annual mean temperature is $-4.94^{\circ} \mathrm{C}$ with the lowest temperature record of $-53^{\circ} \mathrm{C}$. Mean annual precipitation is $432 \mathrm{~mm}$ with relatively dry spring and winter, and moist summer and autumn. The main forest species are Xingan larch (Larix gmelimii), birch (Betula platyphylla), pine (P. sylvestris) and aspen (Populus davidiana). Brown coniferous forest soil is the dominant soil genus with a thickness of $10-30 \mathrm{~cm}$ (Xie et al., 2007).

Based on the following criteria: (i) representativeness of the stands; (ii) accessibility; and (iii) proximity to an

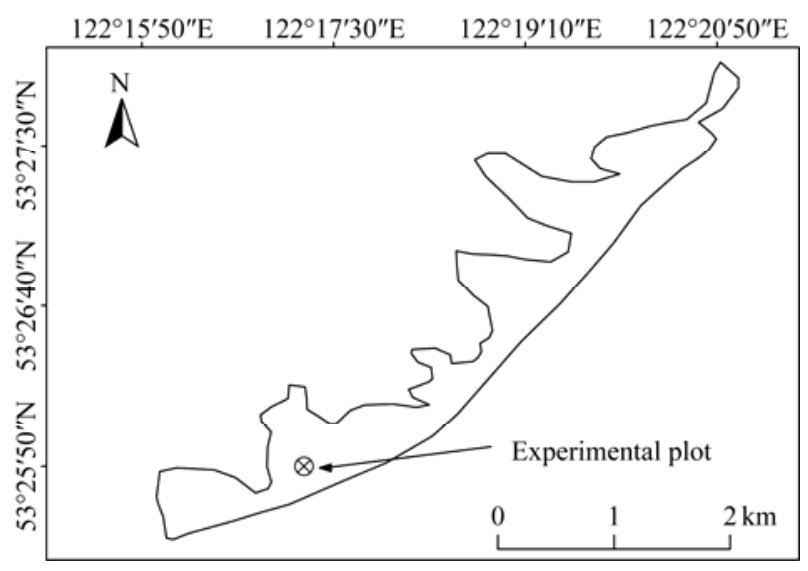

Fig. 1 The location of study region and the distribution area of Pinus sylvestris var. mongolica forest in Mohe county of Northeast China 
open clearing where gross precipitation data could be fully collected $\left(53^{\circ} 24^{\prime} 58^{\prime \prime} \mathrm{N}, 122^{\circ} 17^{\prime} 09^{\prime \prime} \mathrm{E}\right)$, we established an experimental plot with size of $20 \mathrm{~m} \times 30$ $\mathrm{m}$ at the core area of the forest. The plot has a relatively gentle slope $\left(<10^{\circ}\right)$, and the altitude of the plot is $570 \mathrm{~m}$ asl. A survey of the forest was conducted in May 2012. The mean stand density of the forest was 429 trees $/ \mathrm{hm}^{2}$. The mean diameter at $1.3 \mathrm{~m}$ above the ground (i.e. diameter at breast height; $\mathrm{DBH}$ ) was $21.03 \mathrm{~cm}$ and the mean tree height is approximately $16 \mathrm{~m}$. The leaf area index (LAI) from May to Sepetember, 2013 was 1.28, 1.34, 1.41, 1.47 and 1.33, respectively. The dominant understory vegetation species are Rhododendron dauricum L. and Vaccinnium vitis-idaea $\mathrm{L}$.

\subsection{Methods}

The measurements in this study were implemented according to the Chinese Forestry Standards of "Observation Methodology for Long-term Forest Ecosystem Research" (State Forestry Administration of the People's Republic of China, 2011). In order to clarify the relationship between the precipitation characteristic and precipitation redistribution in this forest, we divided the gross precipitation into four magnitudes according to the Chinese National Standards "Grade of Precipitation" (National Meteorological Information Center of the People's Republic of China, 2012). The data were collected from 1 July 2012 to 30 September 2013.

\subsubsection{Gross precipitation}

Incident rainfall $\left(P_{r}, \mathrm{~mm}\right)$ for the forest plot was automatically recorded using a tipping bucket rain gauge (Rain Collector II, Davis Instruments, USA; $0.2 \mathrm{~mm}$ per tip) located in a nearby clearing apart from a distance of $60 \mathrm{~m}$. The orifices of the rain gauge were positioned at $100 \mathrm{~cm}$ above the ground avoiding ground splash effects.

Incident snowfall $\left(P_{s}, \mathrm{~mm}\right)$ was collected by a home-made PVC gutter $(100 \mathrm{~cm} \times 100 \mathrm{~cm})$ which is set up near the rain gauge in clearing apart and also with a height of $100 \mathrm{~cm}$ above the ground. After each snowfall event, we measured the snowfall depth and the snowfall density at four points. The snow water equivalent (SWE) is the depth of the water of melted snowfall. It was calculated by the following equation:

$$
P_{s}=S W E=\frac{\rho_{s} \times S \times S D}{\rho_{w} \times S} \times 10=\frac{\rho_{s} \times S D}{\rho_{w}} \times 10 .
$$

Where $S W E$ is the snow water equivalent $(\mathrm{mm}), S$ is the area of the gutter $\left(\mathrm{cm}^{2}\right), S D$ is the snowfall depth (mm), $\rho_{s}$ is the mean snowfall density $\left(\mathrm{g} / \mathrm{cm}^{3}\right)$ and $\rho_{w}$ is the water density $\left(\mathrm{g} / \mathrm{cm}^{3}\right)$.

\subsubsection{Throughfall}

The throughfall $\left(T_{f}\right)$ was continuously recorded using three tilted gutters $(100 \mathrm{~cm} \times 20 \mathrm{~cm})$ in the plot and five homemade rain gauges $(20 \mathrm{~cm}$ in diameter and 40 $\mathrm{cm}$ in height). Similarly, the gutters and rain gauges were set up $100 \mathrm{~cm}$ above the forest floor for avoiding ground splash and understory effects. Furthermore, the gutters were also set at an angle of $5^{\circ}-10^{\circ}$ to the horizontal, thus the drainage became easy. Each gutter was equipped with a standard rain gauge at its lower end. The measured volumes were corrected for gutter inclination before they were further analyzed. In addition, the gutters were cleaned once a week and regularly treated with silicon solution to prevent clogging by organic debris and to minimize wetting losses, respectively. It is notable that before the homemade gauges was set and used formally, their reliability was examined by comparing them with a standard rain gauge (Rain Collector II, Davis Instruments, USA; 0.2 $\mathrm{mm}$ per tip) in terms of independent trials carried out in an open field. As a result, a linear relationship with a slope of 0.94 (not significantly different from 1) was found between the results of standard and homemade rain gauges and the determination coefficient of the linear equation got an $R^{2}=0.97(P<0.001)$. According to this relationship, data measured by the homemade gauges were corrected.

The throughfall of snowfall precipitation was collected and recorded using five tilted PVC gutters (100 $\mathrm{cm} \times 100 \mathrm{~cm})$ in the plot. They were also set up $100 \mathrm{~cm}$ above the forest floor. We also measured the depth and the density of the snowfall in the gutters after each snowfall event at four different points.

In this study, due to budgetary constraints, we used a larger collection area instead of a larger number of collectors to reduce spatial variability. In addition, the collectors were also randomly relocated once a week to minimize the effects of spatial variability on the magnitude of average throughfall (Lloyd and De O Marques-Filho, 1988). 


\subsubsection{Stemflow}

After the investigation, we divided all the trees into four diameter classes $(<25,25-30,30-35,35-40 \mathrm{~cm})$ Then we selected four average diameter sample trees with average diameters of $18.1,27.7,31.7$ and 38.8 $\mathrm{cm}$, respectively representing the four diameter classes. Total stemflow was monitored at breast heights using collectors made from plastic rings sealed with silicone rubber, providing a watertight junction between the ring and the tree trunk. A pipe connected the ring to the rain gauge (Rain Collector II, Davis Instruments, USA; $0.2 \mathrm{~mm}$ per tip). Manfroi et al. (2004) and Holwerda et al. (2006) found that diameter at breast height relationships for up-scaling to the stand level. For this reason, stemflow at the plot level was estimated by the Eq. 3 .

\subsubsection{Calculation of canopy interception loss}

Canopy interception loss $\left(I_{r}\right.$ for rainfall and $I_{s}$ for snowfall) is the difference between the gross precipitation $\left(P_{g}\right.$, including rainfall and snowfall) falling on top of the canopy (or in an open area) and the net precipitation $\left(P_{n}\right)$ falling through the canopy. Net precipitation $\left(P_{n}\right)$ consists of two components: throughfall $\left(T_{f}\right)$ and stemflow $\left(S_{f}\right)$. Because the stemflow is zero for snowfall, the net precipitation is equal to the snow-throughfall. Hence, the overall canopy interception loss was calculated by the following equations:

$$
\begin{gathered}
I_{r}=P_{g}-P_{n}=P_{g}-\left(T_{f}+S_{f}\right), \\
S_{f}=\frac{1}{M} \sum_{i=1}^{n} \frac{S_{f n}}{K_{n}} M_{n}, \\
I_{s}=P_{s}-P_{n}=P_{s}-T_{f} .
\end{gathered}
$$

Where $S_{f}$ is the stemflow volume $(\mathrm{mm}), M$ is the number of the trees per unit area $\left(\operatorname{trees} / \mathrm{m}^{2}\right)$, and $S_{f_{n}}$ is the stemflow of the sample tree in each diameter class $(\mathrm{mm}) . n$ is the number of trees in its diameter classes. $K_{n}$ is the average projection area of the sample tree $\left(\mathrm{m}^{2}\right)$, while $M_{n}$ is the number of the trees in its diameter class (in tree). $P_{g}$ is the depth of rainfall $(\mathrm{mm})$ and $P_{s}$ is the water depth of melted snowfall $(\mathrm{mm}) . T_{f}$ is throughfall and measured by using the throughfall collectors (mm).

\section{Results}

\subsection{Rainfall}

We recorded 55 rainfall events from July 2012 to
September 2013. Total rainfall amount was 825.47 $\mathrm{mm}$, in which the largest amount was $78.24 \mathrm{~mm}$, the smallest was $0.4 \mathrm{~mm}$. We divided the rainfall into four magnitudes: drizzle $\left(0<P_{r} \leq 10 \mathrm{~mm}\right)$, moderate rain $(10$ $\left.\mathrm{mm}<P_{r} \leq 30 \mathrm{~mm}\right)$, heavy rain $\left(30 \mathrm{~mm}<\mathrm{P}_{r} \leq 50 \mathrm{~mm}\right)$ and rainstorm $\left(P_{r}>50 \mathrm{~mm}\right)$. A total of 37 rainfall events $(67.27 \%)$ did not exceed $10 \mathrm{~mm}$. Eight rainfall events $(14.55 \%)$ were between 10 and $30 \mathrm{~mm}$. There were only four rainfall events $(7.27 \%)$ that exceeded $50 \mathrm{~mm}$, though their combined rainfall was $250.25 \mathrm{~mm}$ and accounted for $30.32 \%$ of the total rainfall. The rainfall intensity values (derived from 5 -min periods) ranged from 1.2 to $67.6 \mathrm{~mm} / \mathrm{h}$, and more than $60 \%$ of the events were drizzle-like with a rainfall intensity of $<5.0 \mathrm{~mm} / \mathrm{h}$ (Fig. 2). In drizzle events, the ratio of the evaporation rate to the rainfall rate is often large, which increased the total canopy interception loss. However, the influence of varying evaporation rates on canopy interception loss was not quantified in this study.

\subsection{Throughfall}

The throughfall amount was $636.63 \pm 47.08 \mathrm{~mm}$ during the study period and accounted for $77.12 \% \pm 5.70 \%$ of the rainfall. The percentage values of $T_{f} / P_{r}$ (Throughfall/rainfall) ranged from $39.27 \% \pm 4.17 \%$ to $86.84 \% \pm$ $3.56 \%$, and the mean value was $69.21 \% \pm 7.03 \%$. After analyzing the relevant rainfall data, we confirmed that the $T_{f}$ and $T_{f} / P_{r}$ increased with the increase of rainfall magnitude. The average percentage values of $T_{f} / P_{r}$ of drizzle, moderate rain, heavy rain and rainstorm were $64.50 \% \pm 7.51 \%, 77.96 \% \pm 9.03 \%, 77.16 \% \pm 4.80 \%$ and $83.41 \% \pm 2.90 \%$, respectively. When the rainfall amount was less than $7.4 \mathrm{~mm}$, the $T_{f} / P_{r}$ ranged from $39.27 \% \pm 4.17 \%$ to $70.58 \% \pm 11.56 \%$ and the coefficient of variation was larger. However, a very strong and significant linear correlation $\left(R^{2}=1.00\right)$ existed between the average throughfall and rainfall (Fig. 3a), while the logarithmic correlation $\left(R^{2}=0.67\right)$ can better describe the relationship between rainfall and $T_{f} / P_{r}$ (Fig. $3 b)$. Besides, throughfall was not observed when rainfall was no more than $0.99 \mathrm{~mm}$. In other words, the canopy storage capacity at saturation was $0.99 \mathrm{~mm}$.

\subsection{Stemflow}

The plot-level estimate of the stemflow was $6.594 \mathrm{~mm}$ and accounted for $0.80 \%$ of the total precipitation. The total stemflow of the four diameter classes were 1.374 , $0.828,2.951$ and $1.441 \mathrm{~mm}$, accounted for $20.83 \%$, 
$12.56 \%, 44.75 \%$ and $21.86 \%$ of the total stemflow, respectively. The stemflow was strongly correlated to rainfall $\left(R^{2}=0.79\right)$ (Fig. 4a). Except for the diameter of $38.8 \mathrm{~cm}$, stemflow increased with the increase of di- ameters, and the stemflow of each sample tree was also strongly correlated to rainfall (Fig. 4b). Our results also implied that stemflow occurred when the gross precipitation exceeded $4.8 \mathrm{~mm}$.
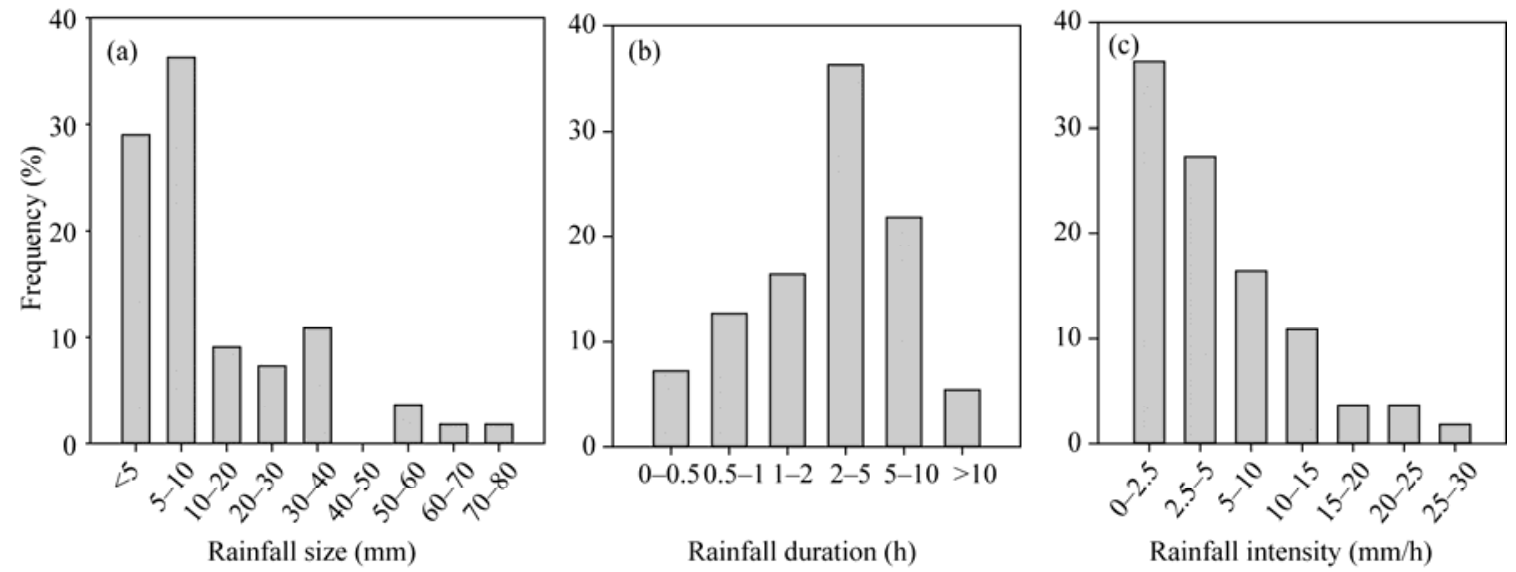

Fig. 2 Frequency distributions of size (a), duration (b) and intensity (c) of rainfall events at the study plot
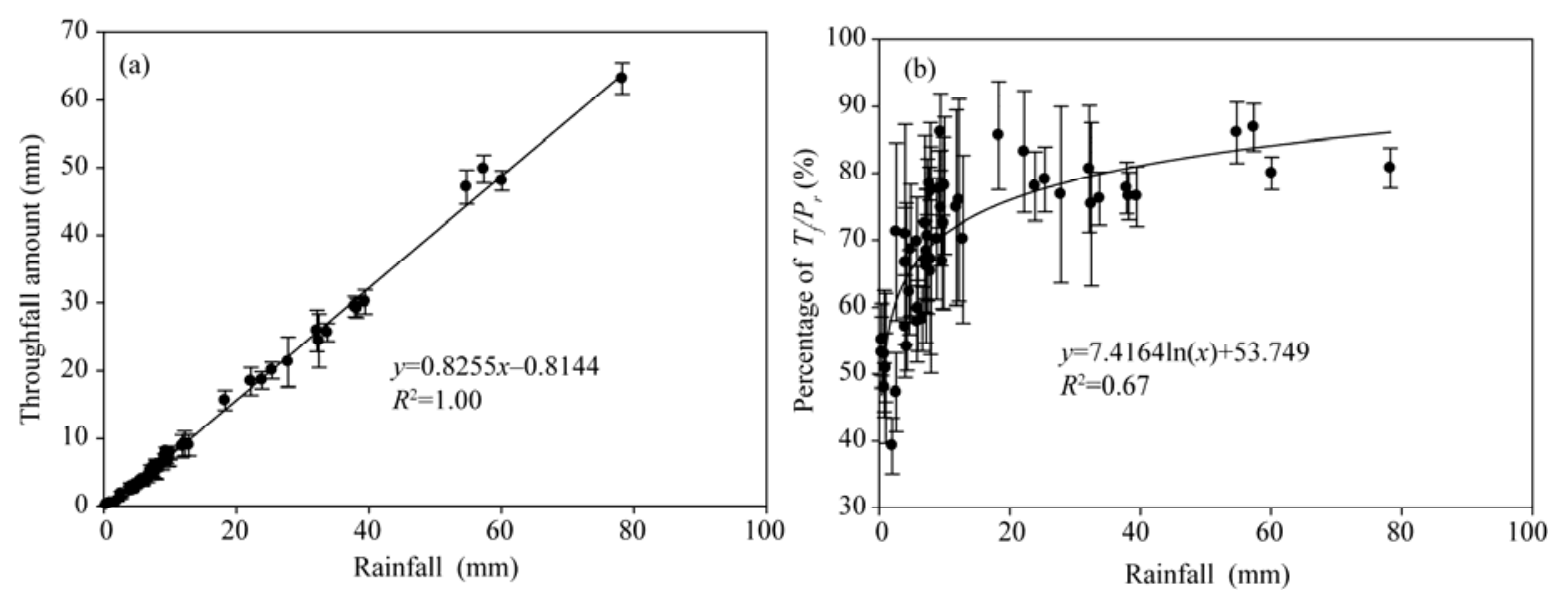

Fig. 3 Correlations between rainfall and throughfall (a), rainfall and percentage of $T_{f} / P_{r}(b)$
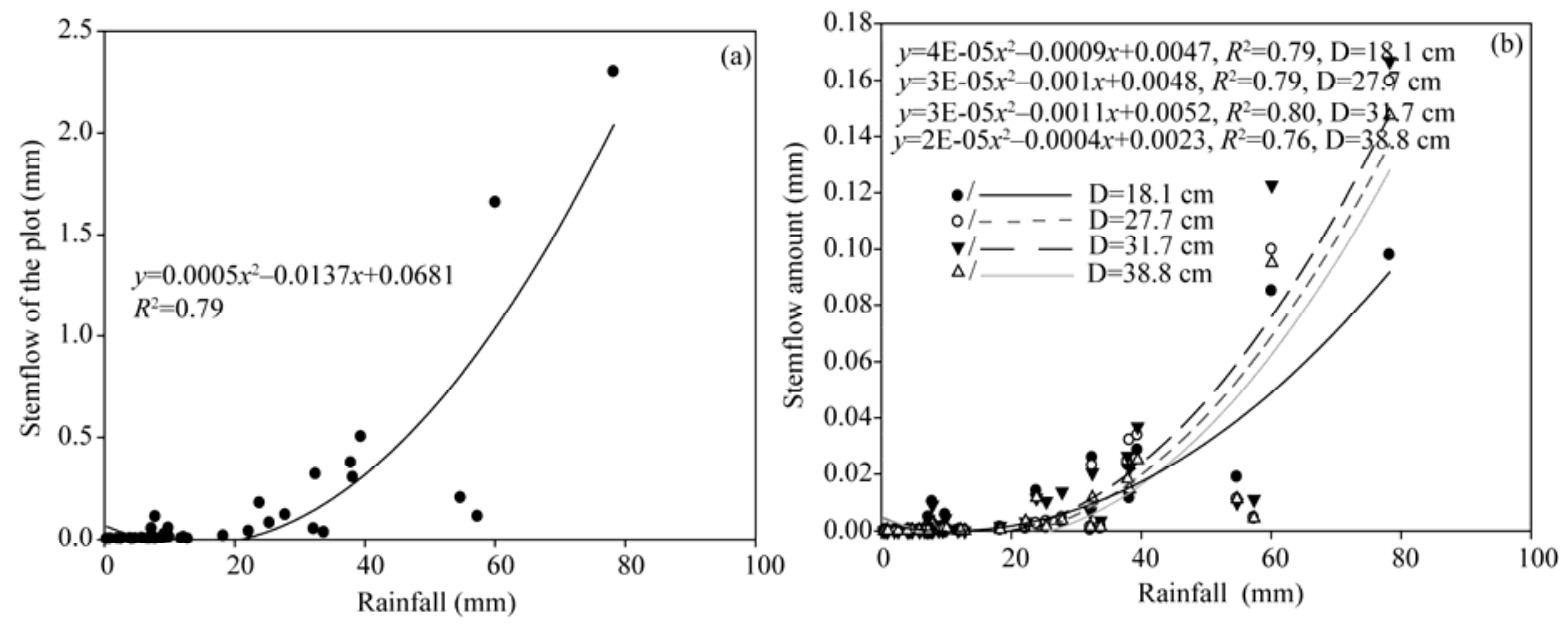

Fig. 4 Correlations between rainfall and stemflow of the plot (a), rainfall and stemflow amount of different diameters (b) 


\subsection{Rainfall interception}

According to our observations, the amount of rainfall interception loss was $182.25 \pm 45.46 \mathrm{~mm}$, which accounted for $22.08 \% \pm 5.51 \%$ of the rainfall. Given single rainfall event, the value of rainfall interception loss ranged from $12.97 \% \pm 3.56 \%$ to $60.72 \% \pm 4.17 \%$, with an average value of $30.49 \% \pm 7.00 \%$. Furthermore, the rainfall interception loss presented a decreasing trend with an increasing rainfall magnitude (Table 1). Monthly rainfall interception loss analysis showed that there were no seasonal trends in the rainfall interception loss (Fig. 5c), which is consistent with the fact that LAI changes are negligible over the rainy season in this forest. There was a significant linear correlation $\left(R^{2}=0.92\right)$ between the rainfall interception loss and rainfall (Fig. 5a) but a logarithmic correlation $\left(R^{2}=0.69\right)$ between the rate of rainfall interception loss and rainfall (Fig. $5 b$ ).

\subsection{Snowfall interception}

We observed a total of 14 snowfall events. The snowfall events were also divided into four magnitudes: light snow $\left(0 \leq P_{s}<2.5 \mathrm{~mm}\right)$, moderate snow $\left(2.5 \mathrm{~mm} \leq P_{s}<5\right.$ $\mathrm{mm})$, heavy snow $\left(5 \mathrm{~mm} \leq P_{s}<10 \mathrm{~mm}\right)$ and blizzard $\left(P_{s} \geq 10 \mathrm{~mm}\right)$. The amount of the snowfall interception loss was $16.20 \pm 0.91 \mathrm{~mm}$, which accounted for $21.39 \% \pm 1.21 \%$ of the snowfall. There was also a liner correlation $\left(R^{2}=0.94\right)$ between the snowfall interception loss and the snowfall (Fig. 6a). We found that the snowfall interception loss was higher in the heavy snow than in the other three magnitudes. The snowfall interception for the four magnitudes accounted for $34.09 \% \pm$ $4.22 \%, 18.12 \% \pm 4.00 \%, 21.31 \% \pm 1.52 \%$ and $21.98 \% \pm$ $1.86 \%$ of the snowfall precipitation, respectively (Fig. $6 b)$.

Table 1 The characteristics of rainfall interception loss at different rainfall magnitudes

\begin{tabular}{cccc}
\hline $\begin{array}{c}\text { Rainfall } \\
\text { magnitude }\end{array}$ & $\begin{array}{c}\text { Rainfall } \\
(\mathrm{mm})\end{array}$ & $\begin{array}{c}\text { Rainfall } \\
\text { interception loss } \\
(\mathrm{mm})\end{array}$ & $\begin{array}{c}\text { Rainfall } \\
\text { interception } \\
\text { loss rate (\%) }\end{array}$ \\
\hline Drizzle & 206.70 & $64.23 \pm 16.79$ & $31.07 \pm 4.70$ \\
Moderate rain & 154.41 & $32.68 \pm 13.47$ & $21.16 \pm 8.72$ \\
Heavy rain & 213.91 & $47.35 \pm 9.98$ & $22.14 \pm 4.66$ \\
Rainstorm & 250.45 & $37.99 \pm 7.17$ & $15.17 \pm 2.86$ \\
\hline
\end{tabular}
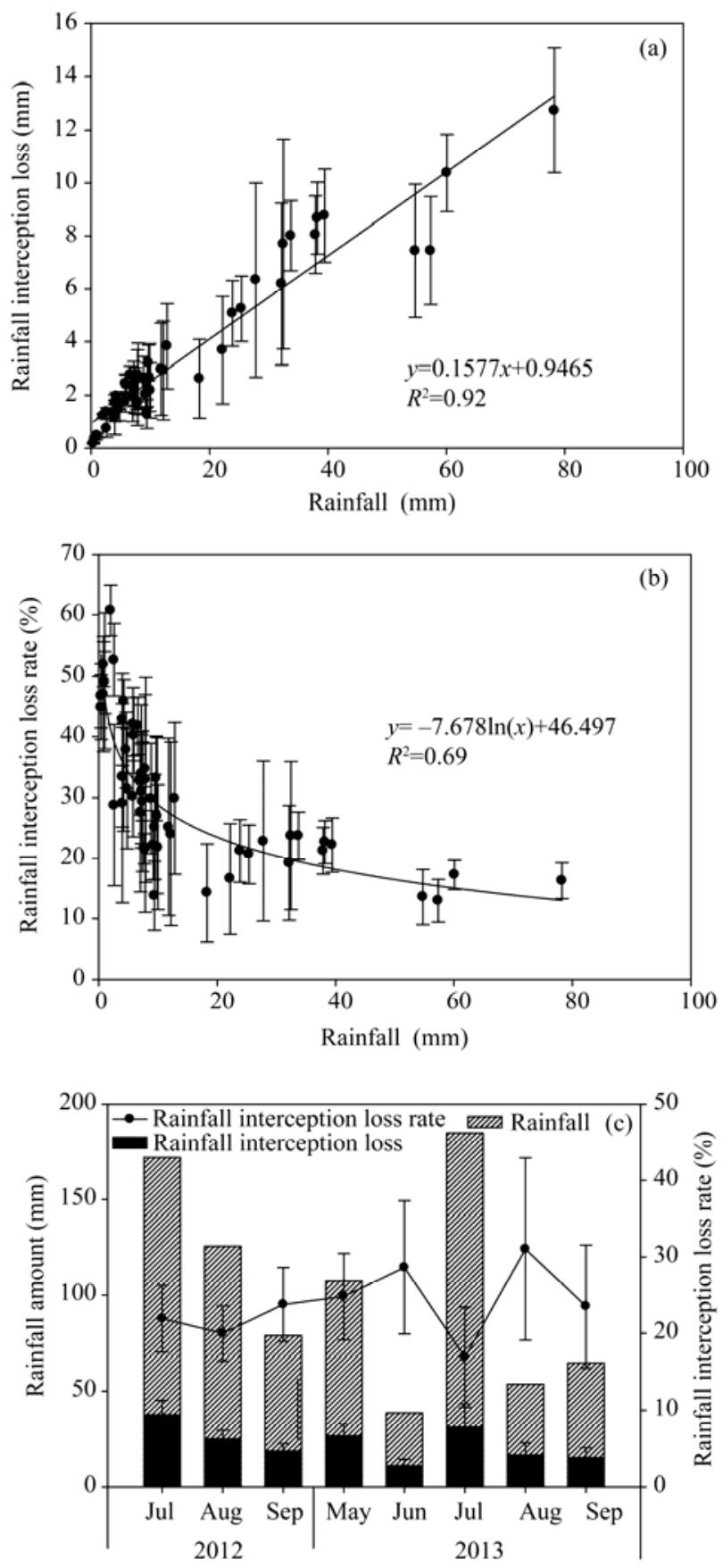

Fig. 5 Correlations between rainfall and rainfall interception loss (a), rainfall and rainfall interception loss rate (b). Characteristics of rainfall amount and rainfall interception loss rate in different months (c).

\section{Discussion}

\subsection{Throughfall}

As the species of our research is a pine forest, the throughfall has a higher spatial variability. At present, it is not possible to accurately estimate the throughfall 

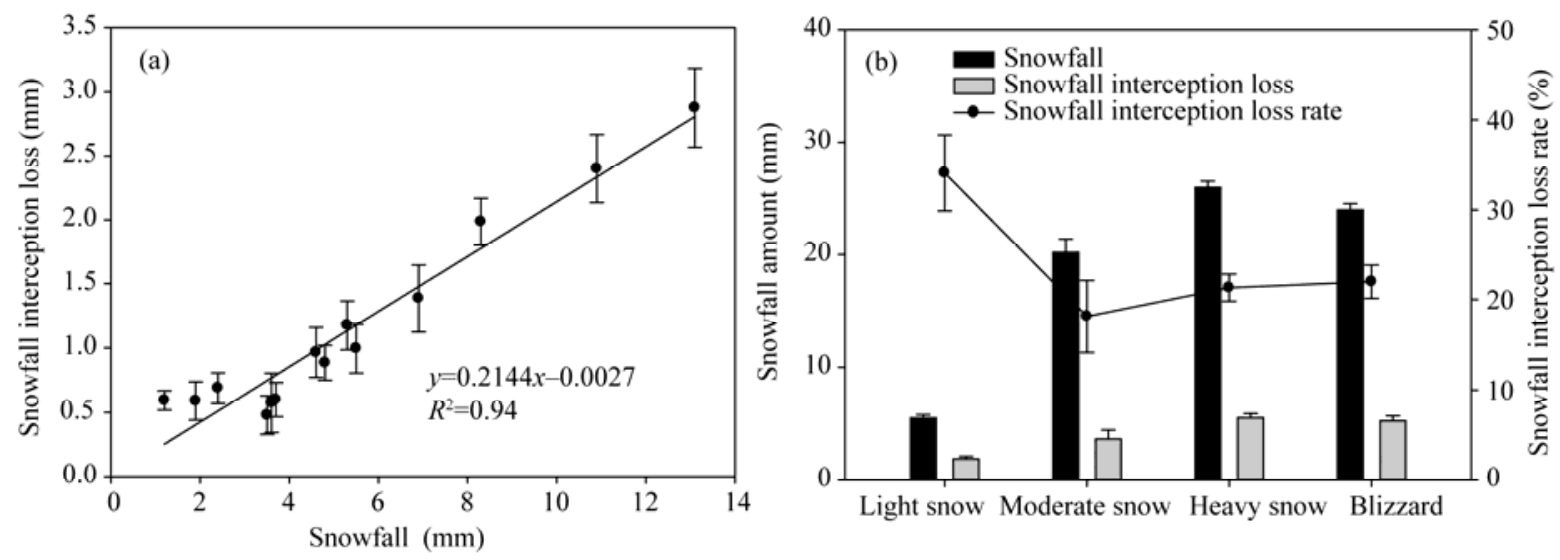

Fig. 6 (a) The correlation between snowfall precipitation and snowfall interception loss; and (b) the characteristics of snowfall interception loss in different snowfall magnitudes

or canopy interception loss using a minimum number of collectors because of difficulties in achieving a robust spatial representation of throughfall measurements (Lawrence and Fernandez, 1993). Rodrigo and Àvila (2001) found that under a dense, coppiced holm oak canopy (which, in terms of density and structure, can to some extent be compared to a hawthorn hedge) 10 gauges with a diameter of $10 \mathrm{~cm}$ were sufficient to ensure that net rainfall was measured with less than $10 \%$ error and pointed out that an obvious increase in funnel size would reduce this error. Calder and Rosier (1976) also recommended that the use of rainfall collectors covering a large area and thereby accounting for the spatial variation of net rainfall in order to improve the representativeness of measurements was also recommended. In this study, accordingly, we used two methods to reduce the potential errors caused by the high spatial variability, i.e. we expanded the area of the collectors and randomly relocated the collectors once a week to minimize the effects of spatial variability on the magnitude of average $T_{f}$ (Lloyd and De O Marques-Filho, 1988). So the array and the size of rain gauges used in the present study can be considered as suitable to account for random spatial variability of throughfall. Above the rain collectors that received consistently much more throughfall than the average, we observed a downward curving branch that acted as a funnel and led to the high level of collected throughfall. This type of canopy feature is not easy to parameterize but may strongly affect the spatial distribution of the throughfall.

\subsection{Stemflow}

There is no protocol existed to measure stemflow (Levia and Frost, 2003) and stemflow has large spatial variability in forests. Compared with throughfall, stemflow representes a small component of the cumulative plot-scale understory precipitation flux. A review of the literature suggests that stemflow averages $3 \%-6 \%$ of season-long or annual gross precipitation in foliated deciduous forests (Helvey and Patric, 1965; Neary and Gizyn, 1994; Carlyle-Moses and Price, 1999). However, stemflow production in Larix gmelinii forest of the study region has been found to be inconsequential with a value of $0.14 \%$ of gross precipitation being measured by Sheng et al. (2014). Nonetheless, Herwitz (1987) thought stemflow was an important water flux in forest ecosystems, delivering an average of 21 times more water to the base of these plants than the gross precipitation equivalent. The stemflow is produced only when the canopy, bark and trunk are all wet and the rainfall is continuous. Therefore, stemflow occurs when the rainfall amount is beyond the critical value (Martinez-Meza and Whitford, 1996; Aboal et al., 1999). In our study, the critical value of the $P_{r}$ was $4.8 \mathrm{~mm}$ and was smaller than those of other species in previous studies (Gong et al., 2005; Chen et al., 2012). The smaller value could be attributed to the structure, the canopy or the tree height of different forests. We also confirmed that when the rainfall is abundant, the stemflow amount increased with the increase of diameters (except the 
sample tree of $D=38.8 \mathrm{~cm}$ ). The reason for this is that larger trees need heavier rainfall to generate high stemflow volumes and to increase their contribution to total stemflow in the plot (Manfroi et al., 2004). However, there were not enough heavier rainfall events during our observation period. Thus, a little strange result occurred at the sample tree of $\mathrm{D}=38.8$ $\mathrm{cm}$. Since the canopy, bark and tree trunk might be different in different diameter classes, the critical value of $P_{r}$ might not be the same. Given the difference in diameter is not significant in our plot, we can arbitrarily conclude that the critical values of the $P_{r}$ in different diameter classes are the same.

\subsection{Rainfall interception loss}

We noticed that when $P_{r}<9.4 \mathrm{~mm}$, the rainfall interception loss rate declined faster with the increase of the rainfall amount. We can regard this value as the inflection point at which the rainfall interception rate experiences a significant change. The accumulated canopy interception loss for this forest was $22.08 \% \pm$ $5.51 \%$. However, the present estimates are comparable with preliminary values reported for similar forest types in other different regions of China. Compared with the values $(18.86 \%, 18.80 \%$ and $21.71 \%$ ) of the dominant Larix gmelinii forest in other regions (Zhou, 2003; Sheng et al., 2009, 2010), the rainfall interception loss of $P$. sylvestris was higher. This higher value may be resulted from two reasons. First, more drizzles occurred during our study period, and the rainfall interception loss in drizzles is much higher than those in the other magnitudes of precipitation. In addition, the canopy of $P$. sylvestris is larger than that of L. gmelinii, and the leaves are longer and can adsorb more rainfall. Rainfall adsorbed by bark is always ignored and combined into the rainfall interception loss. However, P. sylvestris has thicker bark than that of L. gmelinii, which also led to the high value of rainfall interception loss. Compared with the Moso bamboo forest in the subtropics (29.4\%) (Huang et al., 2009) and Picea crassifolia forest (34.8\%) (Gong et al., 2005), the P. sylvestris has the lower inteception loss. The canopy density of the Moso bamboo forest is higher, and the canopy of the $P$. crassifolia is thicker, therefore, the rainfall interception loss of such both forests is higher than that of $P$. sylvestris forest. Since the LAI of $P$. sylvestris forest was similar from May to September, the $T_{f}$ fraction was depended on the stem density. And the lower $T_{f}$ was most likely resulted from the higher evaporation rates during rainfall events, which caused more intercepted rainfall water back to air and thus reduced throughfall through the canopy. However, for this particular arid region, a very large fraction of the rainfall reaching the ground is necessary for the development of trees. Therefore, a suitable stem density may be important in afforestation of arid region.

\subsection{Snowfall interception loss}

The $P$. sylvestris is the only evergreen tree in the north slope of the Great Khingan Mountains. In this region, there is nearly half a year of winter. In the early spring, the type of water supply is snowmelt water. Therefore, the observation of snowfall interception loss should be meaningful. In our study, we determined that the snowfall interception loss rate was $21.39 \% \pm 1.21 \%$, which was only slightly lower than the rainfall interception loss rate $(22.08 \% \pm 5.51 \%)$. The lower temperature in winter than in summer, may lead to a slower canopy evaporation in winter compared to summer. As this is the first time that the snowfall interception losses are being measured in the Great Khingan Mountains, our present estimates are only comparable with preliminary values reported for similar forest types in the Lesser Khingan Mountains. Because of the leaves of $P$. sylvestris minimally fell in winter compared with the snowfall interception loss rate of the original broad-leaved Pinus koraiensis forest (21.2\%), Betula platyphylla forest (8.5\%) and $L$. gmelinii forest (16.3\%) (Liu et al., 2012), the value of our studied forest is higher. However, the value is lower than those of P. koraiensis (28.2\%) and Picea abies forests (39.7\%) (Liu et al., 2012), that was caused by the higher densities of those two forests (1,500 trees $/ \mathrm{hm}^{2}$ for P. koraiensis forest and 475 trees $/ \mathrm{hm}^{2}$ for Picea abies forest) and their larger canopies. As the canopy interception loss of the snowfall in our study is preliminary, there may be some errors in our results due to the limited number of snowfall events. In future studies, we will observe snowfall events over a longer period of time. And we only observed the canopy snowfall interception loss and paid no attention to the 
melting speed of the snow in the forest and the duration of snowmelt runoff. All these questions should be addressed in our future studies.

\section{Conclusions}

In this study, we measured precipitation, throughfall and stemflow in a natural Pinus sylvestris var. mongolica forest, and utilized two methods to reduce the potential errors caused by the spatial variability of throughfall. As a result, the measured throughfall, stemflow and derived estimates of rainfall and snowfall interception loss during the main rainy and snowy seasons were $77.12 \% \pm 5.70 \%, \quad 0.80 \%$, $22.08 \% \pm 5.51 \%$ and $21.39 \% \pm 1.21 \%$ of incident rainfall or snowfall, respectively. The interception loss accounted for $22 \%$ of gross precipitation. As for stemflow, it happened only if the rainfall reached 4.8 $\mathrm{mm}$, furthermore, the larger diameter brought the higher amount of stemflow. For a particular region, a very large fraction of rainfall reaching the ground is necessary for the development of trees. So a suitable stem density may be important for afforestation in arid regions. Certainly, for a comprehensive assessment of water conservation capacity of $P$. sylvestris forest, the changes in transpiration of planted forest and soil infiltration capacity with time after reforestation need to be studied as well in the future.

\section{Acknowledgements}

This research was funded by the National Natural Science Foundation of China (31370460). The study was also supported by the CFERN (Chinese Forest Ecosystem Research Network) \& GENE Award Funds for Ecological Papers.

\section{References}

Aboal J R, Morales D, Hernández M, et al. 1999. The measurement and modelling of the variation of stemflow in a laurel forest in Tenerife, Canary Islands. Journal of Hydrology, 221(3-4): 161-175.

Calder I R, Rosier P T W. 1976. The design of large plastic-sheet net-rainfall gauges. Journal of Hydrology, 30(4): 403-405.

Calder I R. 1996. Dependence of rainfall interception on drop size: 1. Development of the two-layer stochastic model. Journal of Hydrology, 185(1-4): 363-378.

Carlyle-Moses D E, Price A G. 1999. An evaluation of the Gash interception model in a northern hardwood stand. Journal of Hydrology, 214(1-4): 103-110.

Chen S J, Chen C G, Zou B C, et al. 2012. Time lag effects and rainfall redistribution traits of the canopy of natural secondary Pinus tabulaeformis on precipitation in the Qinling Mountains, China. Acta Ecological Sinica, 32(4): 1142-1150. (in Chinese)

Gash J H C. 1979. An analytical model of rainfall interception by forests. Quarterly Journal of the Royal Meteorological Society, 105(443): 43-45.

Gerrits A M J, Savenije H H G. 2011. Interception. In: Peter W. Treatise on Water Science, 2. Oxford: Academic Press, 89-101.

Gong H D, Wang K Y, Yang W Q, et al. 2005. Throughfall and stemflow in a primary spruce forest in the subalpine of western Sichuan. Scientia Silvae Sinicae, 41(1): 198-201. (in Chinese)

Helvey J D, Patric J H. 1965. Canopy and litter interception of rainfall by hardwoods of eastern United States. Water Resources Research, 1(2): 193-206.

Herbst M, Rosier P T W, McNeil D D, et al. 2008. Seasonal variability of interception evaporation from the canopy of a mixed deciduous forest. Agriculture and Forest Meteorology, 148(11): 1655-1667.

Herwitz S R. 1987. Raindrop impact and water flow on the vegetative surfaces of trees and the effects on stemflow and throughfall generation. Earth Surface Processes and Landforms, 12(4): 425-432.

Holwerda F, Scatena F N, Bruijnzeel L A. 2006. Throughfall in a Puerto Rican lower montane rain forest: a comparison of sampling strategies. Journal of Hydrology, 327(3-4): 592-602.

Hörmann G, Branding A, Clemen T, et al. 1996. Calculation and simulation of wind controlled canopy interception of a beech forest in Northern Germany. Agriculture and Forest Meteorology, 79(3): 131-148.

Huang J, Hu H B, Zhang J Y, et al. 2009. Canopy interception characteristics of bamboo forests in northern semitropics. Journal of Nanjing Forestry University: Natural Science Edition, 33(2): 31-34. (in Chinese)

Keim R F, Skaugset A. 2003. Modelling effects of forest canopies on slope stability. Hydrological Processes, 17(7): 1457-1467.

Lanly J. 1982. Tropical forest resources. Food and Agriculture Organization of the United Nations (FAO) paper no. 30. Rome: Food and Agriculture Organization of the United Nations. [2014-09-10]. http://www.ciesin.org/docs/002-113/002-113.html.

Lawrence G B, Fernandez I J. 1993. A reassessment of areal variability of throughfall deposition measurements. Ecological Applications, 3(3): 473-480.

Levia D F, Jr, Frost E E. 2003. A review and evaluation of stemflow literature in the hydrologic and biogeochemical cycles of forested and agricultural ecosystems. Journal of Hydrology, 274(1-4): 1-29.

Levia D F, Carlyle-Moses D, Tanaka T. 2011. Forest Hydrology and Biogeochemistry. New York: Springer Science+Business Media, 407-425.

Liu H L, Cai T J, Man X L, et al. 2012. Effects of major forest types of Xiaoxing'an Mountains on the process of snowfall, snow cover and snow melting. Journal of Beijing Forestry University, 34(2): 20-25. (in Chinese)

Lloyd C R, De O Marques-Filho A. 1988. Spatial variability of throughfall and stemflow measurements in Amazonian rainforest. Agriculture and Forest Meteorology, 42(1): 63-73.

Manfroi O J, Koichiro K, Nobuaki T, et al. 2004. The stemflow of trees in a Bornean lowland tropical forest. Hydrological Processes, 
18(13): 2455-2474.

Martinez-Meza E, Whitford W G. 1996. Stemflow, throughfall and channelization of stemflow by roots in three Chihuahuan desert shrubs. Journal of Arid Environments, 32(3): 271-287.

Mitchell D J, Fullen M A, Trueman I C, et al. 1998. Sustainability of reclaimed desertified land in Ningxia, China. Journal of Arid Environments, 39(2): 239-251.

National Meteorological Information Center of the People's Republic of China. 2012. Grade of Precipitation. Beijing: China Zhijian Publishing House, 1-8. (in Chinese)

Neary A J, Gizyn W I. 1994. Throughfall and stemflow chemistry under deciduous and coniferous forest canopies in south-central Ontario. Canadian Journal of Forest Research, 24(6): 1089-1100.

Rodrigo A, Àvila A. 2001. Influence of sampling size in the estimation of mean throughfall in two Mediterranean holm oak forests. Journal of Hydrology, 243(3-4): 216-227.

Roth B E, Slatton K C, Cohen M J. 2007. On the potential for high-resolution lidar to improve rainfall interception estimates in forest ecosystems. Frontiers in Ecology and Environment, 5(8): 421-428.

Rutter A J, Morton A J, Robins P C. 1975. A predictive model of rainfall interception in forests. II. Generalization of the model and comparison with observations in some coniferous and hardwood stands. Journal of Applied Ecology, 12(1): 367-380.

Sheng H C, Cai T J, Zhu D G, et al. 2009. Rainfall redistribution and hydrochemical characteristics in the Larch plantation. Journal of Soil and Water Conservation, 23(2): 79-83. (in Chinese)

Sheng H C, Cai T J, Li Y, et al. 2014. Rainfall redistribution in Larix gmelinii forest on northern of Daxing'an Mountains,
Northeast of China. Journal of Soil and Water Conservation, 28(6): 101-105. (in Chinese)

Sheng X J, Wang S G, Guan D X, et al. 2010. Canopy interception in larch plantations: Measurement and modeling in Eastern Liaoning Mountainous Region. Chinese Journal of Applied Ecology, 21(12): 3021-3028. (in Chinese)

State Forestry Administration of the People's Republic of China. 2011. Observation Methodology for Long-term Forest Ecosystem Research. Beijing: Phoenix Press. [2014-11-8]. http://www.cfern.org/wjpicture/upload/bzgf/bzgf2011-10-10-8-13-3 9.pdf. (in Chinese)

Tsiko C T, Makurira H, Gerrits A M J, et al. 2012. Measuring forest floor and canopy interception in a savannah ecosystem. Physics and Chemistry of the Earth, Parts A/B/C, 47-48: 122-127.

Whelan M J, Anderson J M. 1996. Modelling spatial patterns of throughfall and interception loss in a Norway spruce (Picea abies) plantation at the plot scale. Journal of Hydrology, 186(1-4): 335-354.

Xie F J, Xiao D N, Li X Z. 2007. Forest crown density restoration and influencing factors in the burned area of northern Great Hing'an Mountains of China. Acta Ecologica Sinica, 27(3): 879-888. (in Chinese)

Shachnovich Y, Berliner P R, Bar P. 2008. Rainfall interception and spatial distribution of throughfall in a pine forest planted in an arid zone. Journal of Hydrology, 349(1-2): 168-177.

Zhou M. 2003. Research on the hydrological process and laws of Larix gmelini ecosystem at the Greater Xing'an Mountains. PhD Dissertation. Beijing: Beijing Forestry University. (in Chinese) 